\title{
Familial temporal lobe epilepsy
}

INSERM

\section{Source}

INSERM. (1999). Orphanet: an online rare disease and orphan drug data base. Familial temporal lobe epilepsy. ORPHA:98819

A rare, genetic epilepsy characterized by mostly benign simple or complex partial seizures with autonomic or psychic auras. Seizures occur infrequently, are of short duration and are usually well controlled with medication. Development and cognition are normal. 